\title{
Can Pharmacists be More Effective Regarding the Proper Use of Face Masks by the Public During the COVID-19 Pandemic?
}

\author{
Eczacılar COVID-19 Salgını Sırasında Yüz Maskelerinin Toplum Tarafından \\ Doğru Kullanılmasında Daha Etkili Olabilir mi?
}

\author{
(D) Nesligül ÖZDEMIR*, (D) Melda BAHAP, (D) Ayçe ÇELIKER \\ Hacettepe University Faculty of Pharmacy, Department of Clinical Pharmacy, Ankara, Turkey
}

Key words: Face mask, pharmacist, COVID-19

Anahtar Kelimeler: Yüz maskesi, eczacı, COVID-19

Dear Editor,

COVID-19 disease has spread quickly throughout the world after it was first identified in Wuhan, China. Since the outbreak was accepted as a pandemic by the World Health Organization, governments/health authorities have started to announce and implement preventive and protective measures against the disease. Using face masks is one of these methods of protection. At this point, at the beginning some governments/ health authorities recommended face masks only for those who have respiratory symptoms or are vulnerable to infections. Currently, increasing numbers of agencies and governments are advocating that the general population should wear masks, besides health professionals. The use of a face mask has become common whether the authorities have recommended it or not. For effective prevention and protection from respiratory diseases wearing a face mask in the correct way is an important issue. When the public's behavior during this pandemic is evaluated, it is seen that many do not use masks correctly. Touching the front of the mask, touching the face and other surfaces without washing the hands after removing the mask, and using disposable masks repeatedly are incorrect practices seen among the public. Many bacteria, viruses, and fungi accumulate on the outer surface, especially the inner side of the mask. ${ }^{2}$ In the study conducted by Chughtai et al. ${ }^{2}$ when surgical masks used by healthcare workers were examined, $10 \%$ of the mask users had respiratory virus contamination and the most contamination was observed with adenovirus, bocavirus, and influenza virus. Contamination possibility increased 6 hours after wearing the mask. Although healthcare workers are knowledgeable about the vital function of protective equipment and use it correctly, the public's knowledge and ability regarding correct equipment use appear insufficient. Therefore, incorrect use increases the risk of contamination to both the wearer and those around. When we observe population behavior towards compliance with protective measures for pandemic diseases we see that as well as unchangeable factors such as age and sex, comparable factors such as perceived susceptibility have important impacts. According to Sim et al. ${ }^{3}$ perceived susceptibility appears to be the most significant factor influencing compliance with mask wearing. They suggest that, to increase the public's perceived susceptibility, they should be educated about contagious diseases. Eastwood et al. $^{4}$ stated that the community was more likely to seek information about the outbreak from general practitioners

*Correspondence: E-mail: nesliozdmr@hotmail.com, Phone: +90 5369787251 ORCID-ID: orcid.org/0000-0003-2551-9549

Received: 19.06.2020, Accepted: 22.07.2020

๑Turk J Pharm Sci, Published by Galenos Publishing House. 
and other healthcare professionals than the national health hotline set up for rapid information dissemination during the H1N1 pandemic. Pharmacists, as healthcare professionals effective in providing preventive public health services by delivering necessary health interventions about lifestyle changes in chronic diseases, vaccination, sexual health, and stopping smoking and alcohol consumption, play an important role in consulting during extraordinary situations such as pandemics as well. They can prevent incorrect use of masks by explaining preventive measures to the public during the current pandemic. ${ }^{5}$ They should prioritize giving the necessary information about mask use to the public and make sure that people use masks correctly, which would be of importance especially during shortages. There is no study on this role of pharmacists. We think that pharmacists' contribution to the public as a whole through education about taking preventive measures will improve compliance with preventive measures, and therefore we recommend that studies should be conducted in this direction.

Conflicts of interest: No conflict of interest was declared by the authors. The authors alone are responsible for the content and writing of the paper.

\section{REFERENCES}

1. Feng S, Shen C, Xia N, Song W, Fan M, Cowling BJ. Rational use of face masks in the COVID-19 pandemic. Lancet Respir Med. 2020;8:434-436.

2. Chughtai AA, Stelzer-Braid S, Rawlinson WD, Pontivivo G, Wang Q, Pan Y, Zhang D, Zhang Y, Li L, Maclntyre CR. Contamination by respiratory viruses on outer surface of medical masks used by hospital healthcare workers. BMC Infect Dis. 2019;19:491.

3. Sim SW, Moey KS, Tan NC. The use of facemasks to prevent respiratory infection: a literature review in the context of the Health Belief Model. Singapore Med J. 2014;55:160-167.

4. Eastwood K, Durrheim DN, Butler M, Jon A. Responses to pandemic (H1N1) 2009, Australia. Emerg Infect Dis. 2010;16:1211-1216.

5. Ou HT, Yang YK. Community Pharmacists in Taiwan at the Frontline Against the Novel Coronavirus Pandemic: Gatekeepers for the Rationing of Personal Protective Equipment. Ann Intern Med. 2020;173:149-150. 